\title{
Development of African Earthenware Container Imbedded with Nanosilver Particles for Food Preservation
}

\author{
Djoulde Darman Roger ${ }^{*}$, Bakari Daoudou², Bayoï James², Etoa Francois Xavier ${ }^{3}$ \\ ${ }^{1}$ The Higher Institute of Sahel, University of Maroua, Maroua, Cameroon \\ ${ }^{2}$ Department of Biological Sciences, Faculty of Sciences, University of Maroua, Maroua, Cameroon \\ ${ }^{3}$ Department of Microbiology, Faculty of Sciences, University of Yaoundé I, Yaoundé, Cameroon \\ Email: ${ }^{\text {djoulde@gmail.com }}$
}

Received 12 April 2014; revised 15 May 2014; accepted 30 May 2014

Copyright (C) 2014 by authors and Scientific Research Publishing Inc.

This work is licensed under the Creative Commons Attribution International License (CC BY).

http://creativecommons.org/licenses/by/4.0/

cc) (i) Open Access

\begin{abstract}
With the aim of ameliorating its preservation capacity, silver nanoparticles (0 - $100 \mathrm{~nm}) \mathrm{with} 99.9 \%$ purity and $35 \mathrm{~nm}$ average particle size, were used as building material for earthenware jar, an extremely old container which is still used in rural African villages specifically in North Cameroon. Earth material was dissolved in water at the weight ratio of $5 \%$ to $10 \%$. Silver nanoparticles were then added to the mixture and stirred to prepare $1 \%$ to $5 \% \mathrm{Ag} /$ Earth paste (1 to $5 \mathrm{ppm}) . \mathrm{A}$ grounded metal rotating drum was used to prepare earth embedded nanosilver plates. An n-order mathematic expression was used to evaluate the shelf-live quality and deterioration rate of sorghum porridge preserved in this African earthenware container imbedded with nanosilver particles. Accelerated shelf-life testing was used to predict the shelf life of the product at usual rural storage conditions. The used Arrhenius model indicated that the shelf life of the sorghum porridge stored in African earthenware container imbedded with nanosilver particles can be extended to 14 days at $4^{\circ} \mathrm{C} \pm 1^{\circ} \mathrm{C}, 6$ days at $15^{\circ} \mathrm{C} \pm 5^{\circ} \mathrm{C}$, and 4 days at $30^{\circ} \mathrm{C} \pm 2^{\circ} \mathrm{C}$. The calculated $Q 10$ values were found to be in the range of $1.5-2.0$.
\end{abstract}

\section{Keywords}

Earthenware, Nanosilver, Food Preservation, Food Packaging, Traditional Food

\section{Introduction}

The earthenware jar is an extremely old container which is still used in Rural African villages [1]. Women used to

*Corresponding author.

How to cite this paper: Roger, D.D., et al. (2014) Development of African Earthenware Container Imbedded with Nanosilver Particles for Food Preservation. Journal of Biomaterials and Nanobiotechnology, 5, 139-145.

http://dx.doi.org/10.4236/jbnb.2014.53016 
carry it on their backs to fetch and keep water from spring, to prepare and keep foods, to keep leftovers fresher [2]. Despite its importance, food spoilage is the major drawback which limits its use in African rural area [3]. One of the most promising innovations in food packaging is the use of nanotechnology to develop antimicrobial packaging [4]. Some studies tend to indicate antimicrobial effect of materials that has one or more dimensions of the order of 100 nanometers ( $\mathrm{nm}$ ) or less [5] especially nanosilver particles and nanogold particle [6]. Kyung-Hwan et al. [7] investigated the antimicrobial activity of silver nanoparticles (Ag-NPs) and platinum nanoparticles (PtNPs) aqueous solution, which were prepared using different stabilizer, such as sodium dodecylsulfate (SDS) and poly-( $N$-vinyl-2-pyrrolidone) (PVP), and showed that the growth of Gram-positive (S. aureus) and Gram-negative (E. coli) bacteria was inhibited by Ag-NPs. The applications of nanotechnology in food sector are predicted to grow rapidly in the coming years in developed world. However, in the developing world as many African countries, the trend seems not alike. We thus found it interesting to bring together an extremely advanced technology (nanotechnology) with and extremely old technology (African earthenware) to ameliorate rural African lifestyle in the food preservation and food safety sectors. The objective of this work is to embed earth material with nanosilver particle to produce African earthenware and test its preservative effect.

\section{Materials}

Silver nanoparticles $(0-100 \mathrm{~nm})$ with $99.9 \%$ purity and $35 \mathrm{~nm}$ average particle sizes [8] were purchase through internet. The earth material (fine earth) was collected from rural women specialised in the production of earthenware from sudano-sahelian zone of North Cameroon.

\subsection{Earth Embedded Nanosilver Material and Earthenware Production}

Earth materials were dissolved at the weight ratio of $5 \%$ to $10 \%$ in water. Silver nanoparticles was then added to the mixture and stirred evenly to prepare $1 \%$ to $5 \%$ silver/fine earth paste. The silver was as a solution of $1 \mathrm{mg} / \mathrm{L}$ $(1 \mathrm{ppm})$ leading to a silver/earth concentrations of 1 to $5 \mathrm{ppm}$. A grounded metal rotating drum was used for preparing earth embedded nanosilver plates. The best ratios obtained after antibacterial test were used as fresh earthen paste to produce earthenware.

\subsection{Antibacterial Test of Nanosilver Embedded Earth Material}

$24 \mathrm{~h}$ freshly growth strains of Staphylococcus aureus (Staph., ATCC25923) were cultured overnight in $10 \mathrm{~mL}$ nutrient broth to achieve a turbidity of $10^{8}$ units forming colony (UFC)/mL. Sterilized nutrient agar were dispensed by pouring $15 \pm 2 \mathrm{~mL}$ into each standardflat bottom petri-dish $(15 \times 90 \mathrm{~mm})$ to obtain solid agar before inoculation. Using a $4 \mathrm{~mm}$ inoculating loop, we transfered 10 times diluted inoculums to the surface of the sterile agar by making five streaks covering the central area of a petri-dish. The earthen material was gently pressed to contact intimately agar surface, and then incubated at $37^{\circ} \mathrm{C}$ for 24 hours. Natural earthen material plate was also used as a negative control. All earthen material was prepared with a diameter of $5 \mathrm{~mm}$ for antibacterial test. The best Ag/earth paste ratio which inhibit microorganisms were checked by examining the incubated plates for interruption of growth along the streaks of inoculum, beneath the specimen and for a clear zone of inhibition beyond its edge.

\subsection{Shelf Life Testing of Sorghum Porridge Stored in the Nano-Earthenware}

The best Ag/earth paste ratio which inhibit major microorganisms were used to prepare a series of earthen jars in which $100 \mathrm{mg}$ of sorghum porridge were stored and the microbial kinetics follows upon the time (4 weeks).

Components of shelf life testing included assessing physicochemical and microbiological attributes of the tested foods. The physicochemical attributes tested consist on determination of oxidation rate, while microbial were focus on the determination of Escherichia coli (E. coli, ATCC25922) and Staphylococcus aureus (Staph., ATCC25923) as they're part of most common micro-organisms involved in food deterioration. The test was repeated three times for each specimen. All experiment was conducted at three accelerated shelf life test temperatures and the gained information was used to model the shelf life of sorghum porridge stored at ambient conditions. The Arrhenius model [9] completed by the linear model [10] were used to predict the shelf life of sorghum porridge at different storages conditions. 


\subsection{Storage Condition}

For storing at various conditions, $100 \mathrm{ml}$ of sorghum porridge samples were placed into wide-mouth $473 \mathrm{ml}$ mason jars (Ball, Alltrista Corp., Muncie, IN). The storage temperatures were $4^{\circ} \mathrm{C}, 15^{\circ} \mathrm{C}, 37^{\circ} \mathrm{C}$ and $40^{\circ} \mathrm{C}$. Temperatures and relative humidity of the chambers were monitored using a data logger (model TL 120, Dickson Company, Addison, IL) as describe by Lee et al. [11]. The samples were stored for up to 4weeks at above given tree temperatures.

\subsection{Development of Arrhenius Shelf Life Equations}

The general mathematical expression for the Arrhenius relationship indicated by Labuza, [12] is as follows:

$$
k=k_{0} e^{-E_{A} / R T}
$$

where $k=$ rate constant for deteriorative reaction at temperature $T, k_{0}=$ constant, independent of temperature (also known as the Arrhenius, preexponential, collision or frequency factor), $E_{\mathrm{A}}=$ activation energy (J/mole), $R$ = ideal gas constant $\left(8.314 \mathrm{JK}^{-1} \cdot \mathrm{mol}^{-1}\right)$, and $(T)$ absolute temperature. From above mentioned Equation (1) and considering Robertson, [10] zero or first-order deterioration equation $k_{1} t_{S 1}=k_{2} t_{S 2}$ we derivate the following equation:

$$
\log \left(t_{S 1} / t_{S 2}\right)=E_{A} / 2.3 R\left(1 / T_{1}-1 / T_{2}\right)
$$

where $k_{1}=$ rate constant at $T_{1}, k_{2}=$ rate constant at $T_{2}, t_{S 1}=$ shelf life at $T_{1}$, and $t_{S 2}=$ shelf life at $T_{2}$. The plot of Equation (2) was made by converting the estimated initiation period $\left(t_{S}\right)$ at each of the three storage temperatures to $\log \left(t_{S}\right)$ and the storage temperature to $1 /($ absolute temperature of the storage temperature, $T$ ), and plotting $\log \left(t_{S}\right)$ vs. $1 / T$. From this plot, Arrhenius shelf life equations were determined using regression analysis.

\subsection{Statistical Analysis}

Values are expressed as means \pm standard deviations. Statistical differences were determined by one-way ANOVA. $P<0.5$ was considered to be statistically significant.

\section{Results and Discussion}

\subsection{Antimicrobial Effect of Ag/Earth Paste}

In order to detect the best ratio of Ag/earth paste material, ratio of $1 \%$ to $5 \%$ (1 to 5 ppm), were tested for Staphylococcus aureus (Staph., ATCC25923) growth inhibition. Table 1 give the obtained width of clear zone of inhibition (mm). We can notice that the width of clear zone of inhibition (mm) increase with the Ag/earth paste ratio with the ratio of 5ppm showing the highest rate. Despite the fact that recent review papers suggest that nanosilver may not be hazardous to humans and may result in low internal exposure [13] [14], we preferred using 3 ppm ratio as the best rate, taking into account the possible toxicity effects of nanosilver particle as mentioned by Stebounova et al. [15].

\subsection{Shelf Life Testing of Sorghum Porridge Stored in the Newly Developed Nanosilver Earthenware}

Sorghum porridge quality deterioration was found to fit a zero and first-order mathematical expression as previously indicated by Labuza [12]:

$$
-d A / d t=k(A)^{n}
$$

Table 1. Width of clear zone of inhibition (mm) for Staphylococcus aureus (Staph., ATCC25923).

\begin{tabular}{ccccccc}
\hline Ag/earth paste ratio (\%) & 0 & 1 & 2 & 3 & 4 \\
\hline Width of clear zone of inhibition $(\mathrm{mm}){ }^{1}$ & 0 & $0.6 \pm 0.0$ & $1.6 \pm 0.1$ & $2.0 \pm 0.2$ & $4.7 \pm 0.1$ & $5.3 \pm 0.1$ \\
\hline
\end{tabular}

${ }^{1}$ The width of clear zone of inhibition (mm) was calculated using the following equation: $W=(T-D) / 2$. Where $W=$ width of clear zone of inhibition in $\mathrm{mm} ; T=$ total diameter of test specimen and clear zone in mm; $D=$ diameter of the test specimen in mm. The silver/earth paste ratio with 3 ppm concentration of nanosilver particles where then used to prepare a series of earthen jars for the shelf life testing. 
where $A$ is a quality attribute measured in some units, $n$ is the reaction order, and $k$ is the constant rate. For either zero or first-order deterioration, Robertson, [10] also shown that

$$
k_{1} t_{s 1}=k_{2} t_{s 2}
$$

where $k_{1}=$ rate constant at $T_{1}, k_{2}=$ rate constant at $T_{2}, t_{S 1}=$ shelf life at $T_{1}$, and $t_{S 2}=$ shelf life at $T_{2}$.

The Arrhenius relationship [12] or the linear model [10] can be utilized to describe how much faster or slower a reaction will go if a sample is held at other temperature (i.e., effect of temperature on $k$ ). We use these models to extrapolate sorghum porridge shelf life results from accelerated tests at given storage temperatures $\left(4^{\circ} \mathrm{C}, 15^{\circ} \mathrm{C}\right.$, $37^{\circ} \mathrm{C}$ and $40^{\circ} \mathrm{C}$ ). This was with the aims at estimating sorghum porridge shelf life results under ambient storage conditions during night and days along time in the sudano-sahelian zone of Cameroon. The rate of oxidation of sorghum porridge stored in the developed nanosilver earthenware was determined by plotting the $n$-hexanal level vs storage time (Figure 1). This is according to the fact that the $n$-hexanal level correlated well with the rancid attribute indicating deterioration of the sorghum porridge [11] [16] due to microbial activity. Hexanal level has also been proven to be a good indicator of oxidative rancidity in many other food systems [17] [18]. From the $n$-hexanal vs time plots, linear regressions are derive together with the data points of the initiation period and the propagation period. The $x$-value of the intercept of these linear regressions was determined to be the estimated end of initiation period. This method of analysis was performed for all sorghum porridge samples at each temperature. Figure 1 shows $n$-hexanal vs. time plots for sorghum porridge kept in newly developed earthenware embedded with nanosilver particles stored at $4^{\circ} \mathrm{C}, 15^{\circ} \mathrm{C}, 37^{\circ} \mathrm{C}$ and $40^{\circ} \mathrm{C}$.

The estimated initiation period at $4^{\circ} \mathrm{C}$ was found to be 11 days (Figure 1 ). The same method was used to estimate the initiation period at $15^{\circ} \mathrm{C}, 37^{\circ} \mathrm{C}$ and $40^{\circ} \mathrm{C}$. Initiation periods of 5 days for samples stored at $15^{\circ} \mathrm{C}, 3$ days for samples stored at $37^{\circ} \mathrm{C}$ and $24 \mathrm{~h}$ for samples stored at $40^{\circ} \mathrm{C}$ were recorded (Figure 1). Because the rate of oxidative rancidity accelerates at the onset of the propagation period, the estimated initiation period could be recognized as a conservative shelf life $\left(t_{S}\right)$ at the fourth accelerated-storage temperatures.

Presented results show regressions equations and $R^{2}$ values for the initiation (Table 2) and propagation (Table 3) periods together with corresponding estimated initiation periods $\left(t_{S}\right)$ in weeks for all samples at storage temperatures of $4^{\circ} \mathrm{C}, 15^{\circ} \mathrm{C}, 37^{\circ} \mathrm{C}$ and $40^{\circ} \mathrm{C}$, respectively.

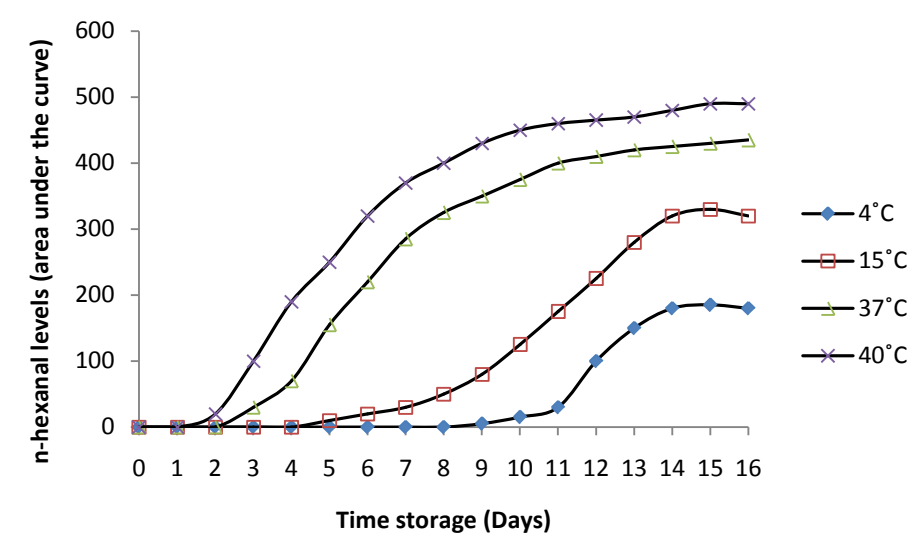

Figure 1. The extent of oxidation of sorghum porridge stored at $4^{\circ} \mathrm{C}$, $15^{\circ} \mathrm{C}, 37^{\circ} \mathrm{C}$ and $40^{\circ} \mathrm{C}$.

Table 2. Regression equations and $R^{2}$ values for initiation and propagation periods of lipid oxidation and the estimated initiation periods for sorghum porridge samples stored at $40^{\circ} \mathrm{C}, 50^{\circ} \mathrm{C}$ and $60^{\circ} \mathrm{C}$.

\begin{tabular}{ccc}
\hline Storage temperature & Regression equation and $R^{2}$ for initiation period & Estimated initiation period $\left(t_{s}\right)$ \\
\hline $4^{\circ} \mathrm{C}$ & $\mathrm{y}=34.33 x+7.720 ; R^{2}=0.875$ & 11 days \\
$15^{\circ} \mathrm{C}$ & $\mathrm{y}=32.99 x+42.2 ; R^{2}=0.916$ & 5 days \\
$37^{\circ} \mathrm{C}$ & $\mathrm{y}=24.13 x-101.5 ; R^{2}=0.872$ & 3 days \\
$40^{\circ} \mathrm{C}$ & $\mathrm{y}=12.47 x-62.57 ; R^{2}=0.700$ & 1 day \\
\hline
\end{tabular}


Table 3. Arrhenius shelf life equation, $R^{2}$, and the estimated shelf life $\left(t_{\mathrm{S}}\right)$.

\begin{tabular}{|c|c|c|c|}
\hline Storage temperature & Arrhenius equation & $R^{2}$ & Estimated shelf life (days) \\
\hline $\begin{array}{l}4^{\circ} \mathrm{C} \pm 1^{\circ} \mathrm{C} \text { (average temperature in the laboratory } \\
\text { refrigerator used for the experiment); }\end{array}$ & $y=1958.5 x-5.40$ & 0.998 & 168 \\
\hline $\begin{array}{l}15^{\circ} \mathrm{C} \pm 5^{\circ} \mathrm{C} \text { (average temperature in a wood cupboard } \\
\text { in sudano sahelian region of Cameroon during winter); }\end{array}$ & $y=1837.2 x-3.85$ & 0.999 & 105 \\
\hline $\begin{array}{l}30^{\circ} \mathrm{C} \pm 2^{\circ} \mathrm{C} \text { (average ambient temperature in } \\
\text { sudano-sahelian region of Cameroon for summer); }\end{array}$ & $y=1792.9 x-4.69$ & 1 & 56 \\
\hline $\begin{array}{l}40^{\circ} \mathrm{C} \pm 3^{\circ} \mathrm{C} \text { (average temperature in a wood cupboard } \\
\text { sudano-sahelian region for summer during the experiment period). }\end{array}$ & $y=1531.2 x-4.67$ & 0.996 & 21 \\
\hline
\end{tabular}

The shelf life of the sorghum porridge was predicted for respectively $4^{\circ} \mathrm{C} \pm 1{ }^{\circ} \mathrm{C}$ (average temperature in the laboratory refrigerator used for the experiment); $15^{\circ} \mathrm{C} \pm 5^{\circ} \mathrm{C}$ (average temperature in a wood cupboard in sudanosahelian region of Cameroon during winter); $30^{\circ} \mathrm{C} \pm 2{ }^{\circ} \mathrm{C}$ (average ambient temperature in sudano-sahelian region of Cameroon for summer) and $40^{\circ} \mathrm{C} \pm 3{ }^{\circ} \mathrm{C}$ (average temperature in a wood cupboard sudano-sahelian region for summer during the experiment period). The results presented (Table 2) indicate that sorghum porridge can be store for 11 day at $4^{\circ} \mathrm{C} \pm 1^{\circ} \mathrm{C}, 5$ days at $15^{\circ} \mathrm{C} \pm 5^{\circ} \mathrm{C}, 3$ days at $37^{\circ} \mathrm{C} \pm 2^{\circ} \mathrm{C}$, and 1 days at $40^{\circ} \mathrm{C} \pm 3^{\circ} \mathrm{C}$.

With shelf life data at two temperatures $10^{\circ} \mathrm{C}$ apart, the $Q_{10}$ factor can be calculated. The $Q_{10}$ factor is defined as the rate of reaction at temperature $(T+10)$ divided by the rate of reaction at temperature $(T)$, which is simply the inverse of the ratio of shelf life at two temperatures $10^{\circ} \mathrm{C}$ apart [19]. $Q_{10}$ were calculated using the linear model shelf life plot as describe by Robertson [10] as follows:

$$
Q_{10}=e^{10 b}
$$

where $b$ is a constant characteristic of the reaction equal to $2.3 \times$ (slope of the linear model plot). The calculated $Q_{10}$ values were found to be in the range of 1.5 - 2.0, which was reported to be the range for lipid oxidation in various food products [12] [20].

Predicted shelf life (indicated by the level of hexanal) for samples stores in the newly developed nanosilver embedded earthenware, in the laboratory refrigerator and samples store at ambient temperature, during winter may be delayed compared to that of the samples stores in a wood cupboard (shown by increase in the shelf life by 2 -fold) and samples stores at ambient temperature and in a wood cupboard in during summer (shown by increase the shelf life by 4 and 16 folds respectively). Water is reported to act as a prooxidant at very low and very high water activities, and to act as an antioxidant between these two extremes [21]. The studied samples may have exhibited differences in the rate of oxidation due to the effect of $a_{w}$ differences, consistent with results shown in the study by Evranuz [22].

Convergence of nanotechnology with other technologies is leading further innovations that are expected to make a major impact on production, processing, storage, transportation, traceability, safety and security of food in developed world. For example, nanotechnology has opened up new opportunities for the development of nano-biosensors for the detection of pathogens and contaminants in food [23]. Such integration of technologies, combined with understanding of taste receptors and flavour perception, is leading to the development of an "electronic tongue" for describing the taste attributes of food [24]. Indeed, the manipulation of substances so close to the molecular level has blurred the boundaries between numbers of traditional food science disciplines and opened up ways to the development of new food textures, tastes and sensations. This new approach of bringing natecthonolgy to rural Africa, is expected to have positive effect in the food safety sector considering the reported quality of food from this part of the world [25].

The issue of food safety in Africa is frequently subjugate to issues of food security, especially in geographic areas where food shortages are caused by recurrent natural phenomena such as drought. In addition, many subsistence farming communities in Africa are reliant on the consumption of home-grown crops, irrespective of the quality considerations normally applied in the developed world [26] [27]. Many of the world's largest food companies are reported to have been actively exploring the potential of nanotechnology for use in food or food packaging but none is done for rural poor population of developing world which cannot afford to buy such food and consume self-produce food. Applications in this area already span development of improved tastes, colour, flavour, texture and consistency of foodstuffs, increased absorption and bioavailability of nutrients and health supplements, new food packaging materials with improved mechanical, barrier and antimicrobial properties, and 
nano-sensors for traceability and monitoring the condition of food during transport and storage. However, this seems to benefit only developed world while problems seem more acute in developing world. The use of nanoparticle to tackle this by developing tools, as this African earthenware embedded with nanosilver particle can contribute to improve food safety issues beside such regions.

Despite the good perspective presented by the newly developed African earthenware embedded with nanosilver it must be mentioned that the rapid proliferation of nanotechnologies in a wide range of consumer products has also raised a number of safety, environmental, ethical, policy and regulatory issues in developed world [28]-[30]. The main concern is the lack of knowledge concerning the interactions of nanosized materials at the molecular or physiological levels and their potential effects and impacts on consumer's health and the environment. The nanotechnology-derived foods are also new to consumers and it remains unclear how public perception, attitudes, choice and acceptance will impact the future of such applications in the food sector. It is, however, well known that uncertainties and lack of knowledge of potential effects and impacts of new technologies, or the lack of a clear communication of risks and benefits, can raise concerns amongst the public [31]. A recent example is the negative public reaction in the EU to genetically modified (GM) crops and GM food [32]. In this context, concerns must be raised over application of nanotechnology for food in developing countries. It is, therefore, important that an appraisal of potential consumer safety and regulatory implications is carried out in the face of actual or potential applications of nanotechnology in the food sector in rural area of Africa.

\section{Conclusion}

Considering that the safety issue of food is one of the major drawbacks which limit the use of foods in rural area and that the issue of food safety in Africa, especially in geographic areas where food shortages are caused by recurrent natural weather phenomena such as drought, African are reliant on the consumption of home-grown crops, irrespective of the quality considerations normally applied in the developed world. The results from acelerated shelf life testing conducted here for sorghum porridge stored in African earthenware embedded with nanosilver particle indicate that the use of such material can enhance the shelf life of food in developing world. However, the main concern is the lack of knowledge in regard to the interactions of nanosized materials and its impacts on consumer's health and environment. It thus remains unclear how rural population perception, attitudes, choice and acceptance will impact the future of such applications.

\section{References}

[1] Mori, J. (1984) The Pottery-Forming Techniques in Bamessing and Vicinity, West Cameroon Minpaku Repository 013 Senri Ethnological Studies (SES) No. 015, Yaoundé, Cameroon, Africa 3.

[2] Jordan, S.C. (2000) Coarse Earthenware at the Dutch Colonial Cape of Good Hope, South Africa: A History of Local Production and Typology of Products. International Journal of Historical Archaeology, 4, 113-143.

http://dx.doi.org/10.1023/A:1009508603336

[3] Mølbak, K., Højlyng, N., Jepsen, S. and Gaarslev, K. (1989) Bacterial Contamination of Stored Water and Stored Food: A Potential Source of Diarrhoeal Disease in West Africa. Epidemiology and Infection, 102, 309-316. http://dx.doi.org/10.1017/S0950268800029988

[4] Bürgers, R., Eidt, A., Frankenberger, R., Rosentritt, M., Schweikl, H., Handel, G. And Hahnel, S. (2009) The Anti-Adherence Activity and Bactericidal Effect of Microparticulate Silver Additives in Composite Resin Materials. Archives of Oral Biology, 54, 595-601. http://dx.doi.org/10.1016/j.archoralbio.2009.03.004

[5] Wilhelmi, B. (2008) Nanosilver: A Test for Nanotech Regulation. Food and Drug Law Journal, 63, 89-112.

[6] Sintubin, L., De Gusseme, B., Van Der Meeren, P., Pycke, B.F.G., Verstraete, W. and Boon, N. (2011) The Antibacterial Activityof Biogenic Silver and Its Mode of Action. Applied Microbiology and Biotechnology, 91, $153-162$. http://dx.doi.org/10.1007/s00253-011-3225-3

[7] Cho, K.-H., Park, J.-E., Osaka, T. and Park, S.-G. (2005) The Study of Antimicrobial Activity and Preservative Effects of Nanosilver Ingredient. Electrochimica Acta, 51, 956-960. http://dx.doi.org/10.1016/j.electacta.2005.04.071

[8] Sun, Y.G. and Xia, Y.N. (2002) Shape-Controlled Synthesis of Gold and Silver. Nanoparticles Science, 13, $2176-2179$. http://dx.doi.org/10.1126/science.1077229

[9] Labuza, T.P. and Riboh, D. (1982) Theory and Application of Arrhenius Kinetics to the Prediction of Nutrient Losses in Foods [Degradation, Keeping, Quality, Temperature, Quality Controls, Analysis, Models]. Food Technology, 36, 66-74. 
[10] Robertson, J. (1993) Deposition Mechanisms for Promoting $\mathrm{sp}^{3}$ Bonding in Diamond-Like Carbon. Diamond and Related Materials, 2, 984-989. http://dx.doi.org/10.1016/0925-9635(93)90262-Z

[11] Lee, Y., Jeon, K., Lee, J.T., Kim, S. and Kim, V.N. (2002) MicroRNA Maturation: Stepwise Processing and Subcellular Localization. The EMBO Journal, 21, 4663-4670. http://dx.doi.org/10.1093/emboj/cdf476

[12] LaBuza, T.P. (1982) Shelf-Life Dating of Foods. Food \& Nutrition Press, Inc., Westport, 387-420.

[13] Nowack, B., Krug, H.F. and Height, M. (2011) 120 Years of Nanosilver History: Implications for Policy Makers. Environmental Science \& Technology, 45, 1177-1183. http://dx.doi.org/10.1021/es103316q

[14] Ahamed, M., Alsalhi, M.S. and Siddiqui, M.K. (2010) Silver Nanoparticle Applications and Human Health. Clinica Chimica Acta, 411, 1841-1848. http://dx.doi.org/10.1016/j.cca.2010.08.016

[15] Stebounova, L.V., Adamcakova-Dodd, A., Kim, J.S., Park, H., O’Shaughnessy, P.T., Grassian, V.H. and Thorne, P.S. (2011) Nanosilver Induces Minimal Lung Toxicity or Inflammation in a Subacute Murine Inhalation Model. Particle and Fibre Toxicology, 8, 5. http://www.particleandfibretoxicology.com/content/8/1/5 http://dx.doi.org/10.1186/1743-8977-8-5

[16] Janvekar, S. (2010) Development and Evaluation of Popped Sorghum Breakfast Cereal for Nutrient Adequacy. The University of Agricultural Sciences, Bangalore.

[17] Warner, K., Frankel, E.N. and Mounts, T.L. (1989) Flavor and Oxidative Stability of Soybean, Sunflower and Low Erucic Acid Rapeseed Oils. Journal of the American Oil Chemists' Society, 66, 558-564. http://dx.doi.org/10.1007/BF02885448

[18] Bovell-Benjamin, A.C., Allen, L.H., Frankel, E.N. and Guinard, J.X. (1999) Sensory Quality and Lipid Oxidation of Maize Porridge as Affected by Iron Amino Acid Chelates and EDTA. Journal of Food Science, 64, 371-376. http://dx.doi.org/10.1111/j.1365-2621.1999.tb15903.x

[19] Mateescu, G.D. and Cabrera, M.E. (1997) In Vivo 170 Magnetic Resonance Spectroscopy. Determination of Temperature Effects on Metabolic Rates (Q10 Factor). Advances in Experimental Medicine and Biology, 411, 585. http://dx.doi.org/10.1007/978-1-4615-5865-1_72

[20] LaBuza, T.P. (1982) Shelf-Life Dating of Foods. Food \& Nutrition Press, Inc., Westport.

[21] Labuza, T.P. and Dugan Jr., L.R. (1971) Kinetics of Lipid Oxidation in Foods. Critical Reviews in Food Science \& Nutrition, 2, 355-405.

[22] Evranuz, E.Ö. (1993) The Effects of Temperature and Moisture Content on Lipid Peroxidation during Storage of Unblanched Salted Roasted Peanuts: Shelf Life Studies for Unblanched Salted Roasted Peanuts. International Journal of Food Science \& Technology, 28, 193-199. http://dx.doi.org/10.1111/j.1365-2621.1993.tb01264.x

[23] Otles, S. and Yalcin, B. (2010) Nano-Biosensors as New Tool for Detection of Food Quality and Safety. LogForum, 6, 7.

[24] Escuder-Gilabert, L. and Peris, M. (2010) Review: Highlights in Recent Applications of Electronic Tongues in Food Analysis. Analytica Chimica Acta, 665, 15-25. http://dx.doi.org/10.1016/j.aca.2010.03.017

[25] Wagacha, J.M. and Muthomi, J.W. (2008) Mycotoxin Problem in Africa: Current Status, Implications to Food Safety and Health and Possible Management Strategies. International Journal of Food Microbiology, 124, 1-12. http://dx.doi.org/10.1016/j.ijfoodmicro.2008.01.008

[26] Shephard, G.S. (2003) Aflatoxin and Food Safety: Recent African perspectives. Toxin Reviews, 22, 267-286.

[27] Tosh, J. (1980) The Cash-Crop Revolution in Tropical Africa: An Agricultural Reappraisal. African Affairs, 79, 79-94.

[28] Colvin, V.L. (2003) The Potential Environmental Impact of Engineered Nanomaterials. Nature Biotechnology, 21, 1166-1170. http://dx.doi.org/10.1038/nbt875

[29] Rogers-Hayden, T. and Pidgeon, N. (2007) Moving Engagement "Upstream”? Nanotechnologies and the Royal Society and Royal Academy of Engineering’s Inquiry. Public Understanding of Science, 16, 345-364. http://dx.doi.org/10.1177/0963662506076141

[30] Balbus, J.M., Maynard, A.D., Colvin, V.L., Castranova, V., Daston, G.P., Denison, R.A. and Wong, B.A. (2007) Meeting Report: Hazard Assessment for Nanoparticles-Report from an Interdisciplinary Workshop. Environmental Health Perspectives, 115, 1654-1659. http://dx.doi.org/10.1289/ehp.10327

[31] Chaudhry, Q., Scotter, M., Blackburn, J., Ross, B., Boxall, A., Castle, L. and Watkins, R. (2008) Applications and Implications of Nanotechnologies for the Food Sector. Food Additives and Contaminants, 25, 241-258. http://dx.doi.org/10.1080/02652030701744538

[32] Gaskell, G., Allum, N., Bauer, M., Durant, J., Allansdottir, A., Bonfadelli, H. and Wagner, W. (2000) Biotechnology and the European Public. Nature Biotechnology, 18, 935-938. http://dx.doi.org/10.1038/79403 
Scientific Research Publishing (SCIRP) is one of the largest Open Access journal publishers. It is currently publishing more than 200 open access, online, peer-reviewed journals covering a wide range of academic disciplines. SCIRP serves the worldwide academic communities and contributes to the progress and application of science with its publication.

Other selected journals from SCIRP are listed as below. Submit your manuscript to us via either submit@scirp.org or Online Submission Portal.
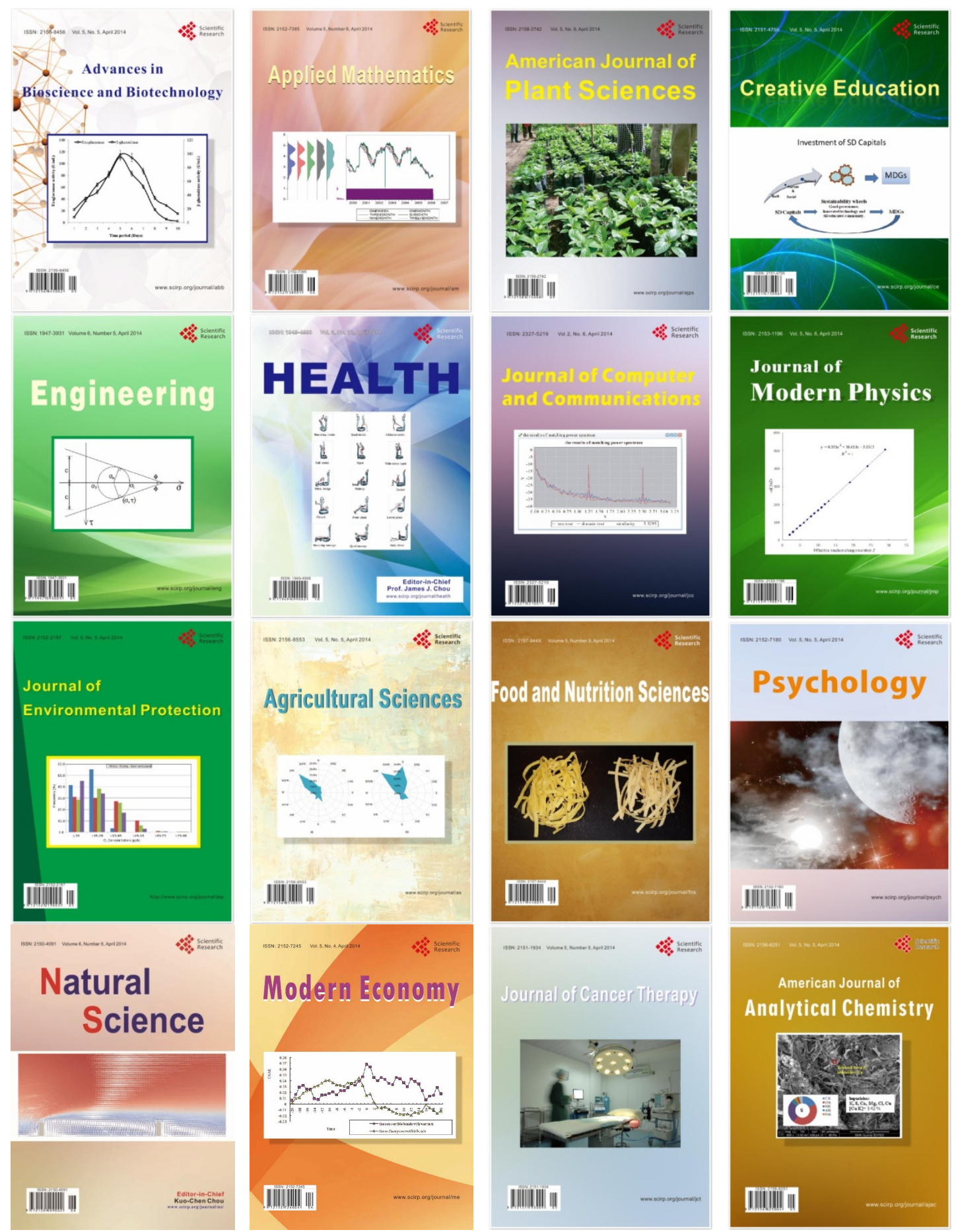